\title{
LAS TRAGEDIAS Y LA VIDA
}

\author{
Eduardo Contreras Soto
}

A Amalia Lejavitzer

$\mathrm{F}_{\text {iloginio de Rodas fue un poeta }}$ trágico del siglo de Pericles. En su mocedad amó con pasión a una esclava fenicia; sin embargo, aunque la poseyó en todos los sentidos, nunca fue amado por ella. El poeta escribió una tragedia inspirada en esa esclava, Anfiarao; en esta obra, la protagonista provoca con su vanidad indiferente la muerte de su esposo. Fue la primera de sus tragedias presentada a un concurso, y perdió frente a Esquilo.

Ya entrado en los treinta años de su edad, Filoginio se prendó de un chico ateniense que apenas rebasaba los quince de la suya. Con él vivió feliz un par de años; pero el chico fue muerto en un ataque espartano a Atenas. El poeta escribió a la memoria de su amado una tragedia, Ganímedes, donde se podía ver cómo Zeus dispensaba la gloria al mancebo de sus deseos. Con esta obra, por cierto, ganó el concurso de tragedias a Sófocles.

A los cuarenta o cuarenta y cuatro años Filoginio se casó con una paisana. Tuvo dos hijos con ella. Al principio se querían mucho el marido y la mujer, pero con el paso de los años a ella se le agrió el carácter y enemistó a los hijos contra su padre, quien también comenzó a agriarse. En aquellos últimos años de su matrimonio compuso el poeta una tragedia, Medea -anterior a la homónima de Eurípides-, en donde, como es sabido, la mujer le mata los hijos al marido.

Filoginio enviudó a los sesenta años. Entonces conoció a una joven prostituta de Lesbos, con la cual comenzó a vivir, y con ella fue dichoso durante los últimos cinco años de su vida. El poeta dejó sin 
estrenar una tragedia escrita poco antes de morir, Alcestes, en la cual un hombre a punto de perder la vida se salva por la intervención de la mujer que ama. La viuda de Filoginio pagó el coro y los hijos del poeta estrenaron la tragedia, ganando para su padre un premio póstumo por encima de Agatón.

El eminente filólogo alemán Siegfried von Freudland, de la escuela psicologista, opinaba que Filoginio de Rodas había tenido con las mujeres muy mala suerte, y que ésta había ido empeorando con los años. Por ende, sus tragedias debían fecharse en el orden siguiente: primero Ganímedes, porque revela un desconocimiento o indiferencia sobre las mujeres, así que el poeta debería haberla escrito en su juventud. Después Alcestes, porque la mujer aún conserva en esta obra valores positivos. A continuación Anfiarao, y al final Medea, porque en ellas las mujeres van provocando sufrimientos progresivamente mayores a los hombres: en la primera la muerte; en la segunda, una vida peor que la muerte.

El admirado filólogo inglés Sir S. B. Spencerson, de la escuela sociologista, tenía algunas discrepancias con su colega alemán, y consideraba que las obras dependían de la posición que iba ganando la mujer en la sociedad de aquella época. Así, Ganímedes le parecía la tragedia más antigua de Filoginio, pues las mujeres en esta obra no tienen participación alguna. Después seguirían Alcestes y Medea, porque en ellas la intervención de las mujeres ya adquiere importancia, aunque cada una se vuelva importante en distinto sentido. Alcestes habría sido escrita antes que Medea, porque en Alcestes, si bien la protagonista realiza la acción principal al salvar una vida, la acción que realiza es justa y está dentro de la ley y la moral: es decir, la mujer todavía no afronta ciertos riesgos ni audacias. En cambio en Medea, como después en Anfiarao, los atrevimientos de la mujer producen efectos nocivos, inmorales, sobre otros personajes, aunque en Medea no afectan de modo activo al principal destinatario de sus odios, es decir, a su esposo. Por lo mismo, Anfiarao tendría que ser la última de 
las tragedias de Filoginio, pues en ella la mujer se hace cargo de sus propias decisiones, y éstas son ilegítimas e inmorales, pues consisten nada menos que en matar al objeto directo de sus sentimientos.

Ni el filólogo alemán ni el inglés, por supuesto, sabían todos estos pormenores de la vida de Filoginio de Rodas que yo me encontré en un viejo códice de un monasterio de Corfú, en cuyas páginas de pergamino se pueden leer las biografías de muchos otros personajes célebres del siglo de Pericles.

México, 26 de junio de 1996. 
La reproducción total o parcial de este artículo se podrá hacer si el ITAM otorga la autorización previamente por escrito. 